\title{
HYDROMETEOROLOGICAL PARAMETERS AND AQUATIC CHEMISTRY OF LAKE ENGURE: TRENDS OF CHANGES DUE TO HUMAN IMPACT AND NATURAL VARIABILITY
}

\author{
Māris Kḷaviņš, Ilga Kokorīte, Valērijs Rodinovs, Zanita Avotniece, Gunta Springǵe, \\ and Agrita Briede \\ Faculty of Geography and Earth Sciences, University of Latvia, Raina bulv. 19, Rīga LV-1586, LATVIA \\ E-mail: maris.klavins@lu.Iv \\ Contributed by Māris Kḷaviṇš
}

Lake Engure, located in Latvia, is the largest shallow coastal lake that developed after retreat of the Littorina Sea. It supports high biodiversity and has national and international importance. Engure is a hardwater lake with abundant macrophyte and charophyte vegetation. The present study determined the impact of the main meteorological indicators related to global warming, and also indicators of climate extremes. The lake water level is regulated by hydrotechnical constructions. In the the warm period (April-October) of the year the lake level tends to increase. However, from a perspective of long-term changes, there was a good relationship between the Western type of Atmospheric Circulation Index and water level in general, and also between NAO index in March and lake water level in April. Regarding water chemical composition, there has been a decrease of phosphorus concentration while ammonium and nitrate concentrations have not changed. Ionic composition of Lake Engure is characterised by dominance of hydrocarbonates, calcium and magnesium ions.

Key words: Lake Engure, hydrometeorological parameters, aquatic chemistry, trends, extremes.

\section{INTRODUCTION}

Lake Engure is located in the western part of the coastal lowland of Latvia and is separated from the Gulf of Riga by a 1.5- to 2-km wide dune zone. Based on origin the lake belongs to the lagoon lake group (Eberhards and Saltupe, 2000). Five rivers flow into the lake. Partly due to its origin, Lake Engure is very shallow; the average depth is $0.4 \mathrm{~m}$ and the maximum depth of $2.1 \mathrm{~m}$ is located in the northeastern part of the lake. The water level was lowered in 1842 when a canal were built connecting the lake with the Gulf of Riga. Lake Engure is characterised by a sandy bedrock with a thick layer of gyttja (maximum thickness is over $2 \mathrm{~m}$ in the southern part of the lake). The lake bed is covered by charophytes, and in the process of mineralization a layer of calcium carbonate is formed. The morphometrical features, canal construction (a lowered water level), and the state of the lake have promoted overgrowing of the littoral zone by macrophytes, mainly by reeds and bulrush. About $65 \%$ of the open water area is covered by higher vegetation (Anonīms, 1995). Lake Engure is the largest shallow coastal lake remaining in the territory of Latvia from the age of the Littorina Sea. The lake supports high biodiversity. In the lake basin, more than 800 vascular plant species have been found and about 185 bird species have been recorded as breeding (Vìksne, 1997). Since 1995, the lake was included in the list of Ramsar sites, and in 1998, Lake Engure Nature Park was established. For management of the lake, it is im- portant to understand the interactions between physical, chemical and biological processes in the lake basin. Knowledge of the character of natural and human-induced pressures and the associated response would aid to understand the character of processes in the lake basin and support development of lake management strategies and action plans.

The aim of this study was to determine trends of changes of hydrometeorological parameters and aquatic chemistry of Lake Engure.

\section{MATERIAL AND METHODS}

Lake Engure is located in the western part of the Coastal Lowland in the western part of the Gulf of Rìga (Fig. 1). It is separated from the sea by a $1-$ to $3-\mathrm{km}$ wide dune zone. Five rivers flow into the lake. A canal was built in 1842 to drain the lake waters to the Gulf of Riga. The surface area of the lake is $40.46 \mathrm{~km}^{2}$, with maximum depth $2.1 \mathrm{~m}$, average depth $0.4 \mathrm{~m}$, and volume 16.8 mill. $\mathrm{m}^{3}$. The mean water retention time is 7.2 per year, and the ratio "catchment area: lake surface" is $15.6: 1$. The lake has sandy bedrock, and sediments are formed mainly by sapropel/gyttja. The lake supports rich submerged, emerged and floating macrophytes (Vîksne, 1997).

Chemical and biological studies of Lake Engure were carried out in the vegetation period (June - July) from 1995 


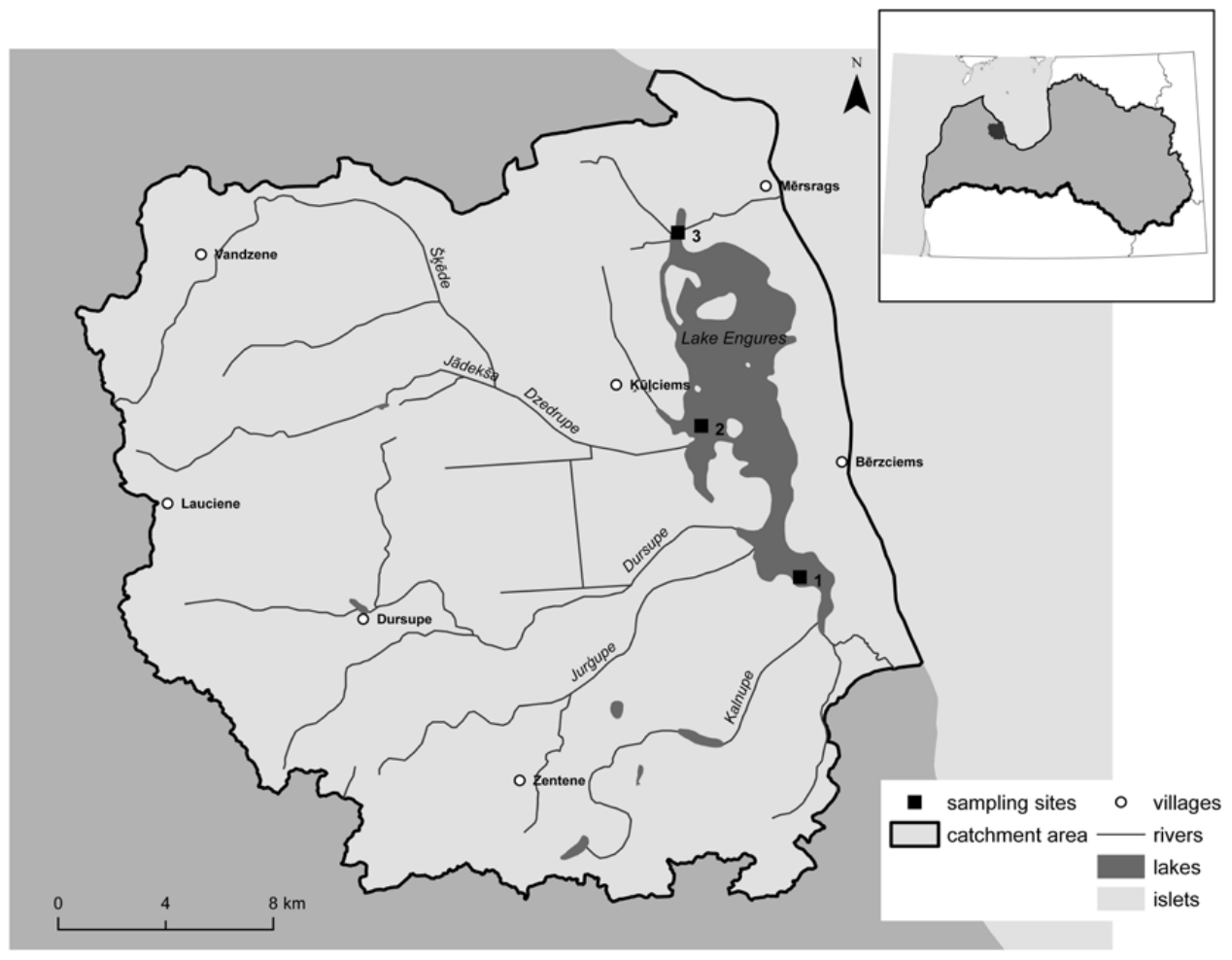

Fig. 1. Location of monitoring sites in Lake Engure.

until 2010. The sampling sites for aquatic chemistry in Lake Engure are distributed evenly in all parts of water body: two stations area located in the central and southern parts close to inflowing rivers. The location of the third station was chosen near the Mērsrags canal to represent sedimentation processes and characterise the impact of the canal zone.

The chemical composition of water was determined by standard methods: colour spectrophotometrically at wavelength $455 \mathrm{~nm}$ in the $\mathrm{Pt} / \mathrm{Co}$ scale; nitrate concentration using diazotisation of gentisic acid after reduction of nitrate with cadmium; and phosphorus with ammonium molybdate (Anonymous, 1992). Inorganic water ingredients were analysed using standard methods (Anonymous, 1992).

Sediment samples were taken in March and October of 2010 using an Ekman sediment grabber. Samples were air dried and homogenised in a mortar.

Sediment aliquots for loss-on-ignition (LOI) analysis were oven dried at $105{ }^{\circ} \mathrm{C}$ for $24 \mathrm{~h}$. Then a sample $(1 \mathrm{~g})$ of was taken for analysis of content of organic matter and carbonates as described by Heiri et al. (2001).

For analysis of heavy metals, $1 \mathrm{~g}$ samples of sediments were digested with $50 \% \mathrm{HNO}_{3}$ and $30 \% \mathrm{H}_{2} \mathrm{O}_{2}$ on a hot plate at $70 \pm 5{ }^{\circ} \mathrm{C}$ (Csuros M. and Csuros C., 2002). Concentrations of $\mathrm{Fe}, \mathrm{Cr}, \mathrm{Mn} \mathrm{Co}, \mathrm{Ni}, \mathrm{Cu}, \mathrm{Zn}, \mathrm{Cd}$ and $\mathrm{Pb}$ were determined by a flame atomic absorption spectrophotometer PerkinElmer Instruments AAnalyst 200. Every extraction batch included blank sample and reference material ISE 1998.3-921 (Wageningen Evaluating Programmes for Analytical Laboratories) to control the quality of measurements.

For trend analysis of climate parameters, time series of annual, and monthly and seasonal parameters were obtained from the Mērsrags meteorological station, which was the closest station to the lake. Temperature at this station was recorded starting in 1895, but with gaps during war periods. In the present study, temperature and precipitation data from 1928 were used. Trends were analyzed using a nonparametrical Mann-Kendall test (Libiseller and Grimvall, 2002). The Mann-Kendall test was applied separately to each variable; the trend was considered as statistically significant at the $P \leq 0.05$ if the test statistic was greater than 1.96 or less than -1.96 .

Observations of water level in the lake during the warm period of the year (IV-X) have been made since 1970 by ornithologists A. Mednis and J. Kazubiernis of the Institute of Biology, University of Latvia. Data on lake level changes were also obtained from Latvian Environment, Geology and Meteorology Centre.

The North Atlantic Oscillation (NAO) index (Anonymous, 2011) was used to examine the relationship between largescale atmospheric processes and water level in Lake Engure. Large-scale atmospheric circulation has been studied using catalogues of indexes of atmospheric circulation (ACI). The Arctic and Antarctic Research Institute, St. Petersburg, Russia has produced a catalogue of the daily forms of the Atlantic-Eurasia atmospheric circulation processes since 1891 , which has been successful used to provide long-term forecasts for the $\mathrm{W}, \mathrm{E}$ and $\mathrm{C}$ processes (Girs, 1971; Jaagus, 2006).

The analysis of meteorological parameters is based on daily, monthly and annual data series (1928-2010) for the Mērsrags meteorological station (Fig. 1). This data was obtained from the Latvian Environment, Geology and Meteorology Centre. 


\section{RESULTS}

Climate of the Lake Engures basin. Lake Engure is located in the transition zone between maritime and continental climate, where winters are milder and summers are colder and wetter than in regions with a typical continental climate. The mean annual air temperature in this region is $+5.7^{\circ} \mathrm{C}$. The beginning of the vegetation period mostly occurs in the middle of April, and ends around October 22. The last spring frosts are usually observed around May 23. The first snow usually occurs around November 20. The ground becomes is covered with a stable snow from about a month later till March 15. Precipitation exceeds evaporation by two times, and also the relative humidity is high - on average $76 \%$. The prevailing winds are south-westerly and southerly.

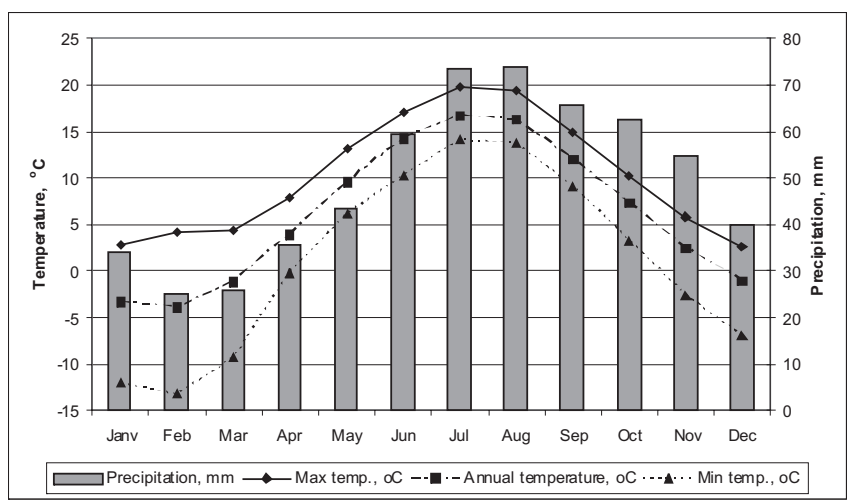

Fig. 2. Average monthly air temperatures and precipitation sum at the Mērsrags meteorological station (1928-2007).

Air temperature started to be regularly recorded at the meteorological station Mērsrags have started in 1928 (Fig. 2). The coldest month during the year is February, with average air temperature $-3.9^{\circ} \mathrm{C}$. The warmest month is July with average air temperature $+16.7^{\circ} \mathrm{C}$. Inter-annual variability of mean monthly temperature is highest in January and February, with standard deviations of 3.4 and 4.1, respectively. the lowest variability (standard deviation 1.3) in mean monthly temperature occurs in August and September. The mean annual precipitation sum at Mērsrags for the studied period was $593 \mathrm{~mm}$. Generally, the largest precipitation sum occurs in summer and early autumn (July, August and September); the driest months are February and March.

To assess long-term trends of climate variables at Mērsrags meteorological station, ensemble climate change indices were derived for the period 1928-2010 (Fig. 3, Tables 1, 2) from daily temperature and precipitation data. These indices describe changes in the mean values of climatic variables and extremes of climate. The indices follow the definitions recommended by the CCl/CLIVAR/JCOMM Expert Team on Climate Change Detection and Indices, with a primary focus on extreme events (Klein Tank, 2004).

The trend was considered as statistically significant at the $5 \%$ level if the test statistic was greater than 1.96 or less than -1.96 .

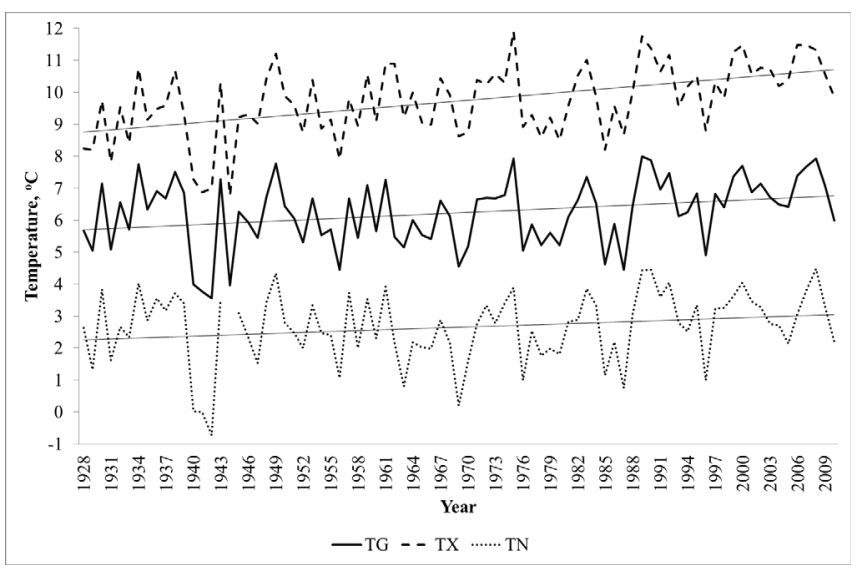

Fig. 3. Trends in the annual mean of minimum (TN), maximum (TX) and mean (TG) air temperatures at the Mērsrags meteorological station for the period 1928-2010.

Table 1

LONG-TERM TRENDS IN METEOROLOGICAL EVENTS CHARACTERISING CLIMATE VARIABILITY AT THE MĒRSRAGS METEOROLOGICAL STATION FOR THE PERIOD 1928-2010 (Man-Kendall test statistics)

\begin{tabular}{c|c|c|c|c|c}
\hline TG & TX & TN & DTR & GD4 & GSL \\
\hline $\mathbf{2 . 5 2}$ & $\mathbf{4 . 3 6}$ & 1.51 & $\mathbf{5 . 2 3}$ & 1.48 & 0.40
\end{tabular}

TG, mean daily mean temperature, ${ }^{\circ} \mathrm{C}$; TN, mean daily minimum temperature, ${ }^{\circ} \mathrm{C}$; TX. mean daily maximum temperature, ${ }^{\circ} \mathrm{C}$; DTR, mean diurnal temperature range, ${ }^{\circ} \mathrm{C}$; GD4, growing degree days (sum of $\mathrm{TG} 4{ }^{\circ} \mathrm{C}$ ), ${ }^{\circ} \mathrm{C}$; GSL, growing season length, days. The trend was considered as statistically significant at the $5 \%$ level if the test statistic was greater than 1.96 or less than -1.96 .

Table 2

LONG-TERM TRENDS IN EXTREME METEOROLOGICAL EVENTS AT THE MĒRSRAGS METEOROLOGICAL STATION FOR THE PERIOD 1928-2010 (Man-Kendall test statistics)

\begin{tabular}{c|c|c|c|c|c|c|c}
\hline $\mathrm{SU}$ & TR & ID & FD & CFD & CSDI & HP & VHP \\
\hline $\mathbf{4 . 1 3}$ & 1.75 & -1.46 & -1.37 & -1.56 & -1.31 & $\mathbf{4 . 0 1}$ & $\mathbf{2 . 6 1}$
\end{tabular}

HP, heavy precipitation ( $\geq 10 \mathrm{~mm}$ ), days; VHP, very heavy precipitation $(\geq 20 \mathrm{~mm})$, days; FD, frost day $\left(\mathrm{TN}<0{ }^{\circ} \mathrm{C}\right)$, days; ID, ice day $\left(\mathrm{TX}<0{ }^{\circ} \mathrm{C}\right)$, days; $\mathrm{SU}$, summer day $\left(\mathrm{TX}>25^{\circ} \mathrm{C}\right)$, days; $\mathrm{TR}$, tropical night $(\mathrm{TN}>20$ $\left.{ }^{\circ} \mathrm{C}\right)$, days; CFD, maximum number of consecutive frost days $\left(\mathrm{TN}<0{ }^{\circ} \mathrm{C}\right)$, days; CSDI, cold-spell days, days.

Trend analysis of meteorological events (Tables 1, 2) indicates not only increasing trends of average temperature indicators, but also several indicators of climatic extremes.

Lake level changes. The hydrological regime of Lake Engure is regulated by a canal, built in 1842 , which connects it with the Gulf of Rīga. The canal lowered the water level in the lake by $1.5 \mathrm{~m}$. The water volume has decreased by more than twice since the early $20^{\text {th }}$ century, from 43 million $\mathrm{m}^{3}$ to 16.8 million $\mathrm{m}^{3}$, which resulted in overgrowing of a large part of the lake by macrophytes.

Mann-Kendall trend tests showed a statistically significant positive trend of long-term water level changes for the 


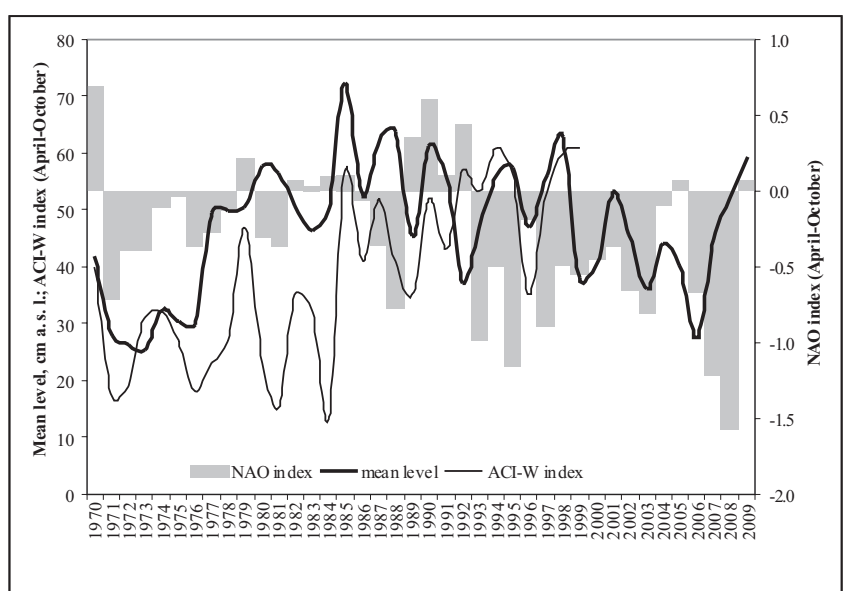

Fig. 4. Long-term change of water level in Lake Engure level with NAO index and the Western type of Atmospheric Circulation Index (ACI-W).

warm period only for water level in July (test statistic 2.37; $P<0.01$ ), but long-term changes for the warm period (April-October) was not significant.

The relationship of the large-scale atmospheric circulation with water level was investigated using NAO monthly and seasonal indexes. In general, the obtained results indicated a rather weak relationship between these parameters. A significant positive correlation coefficient $\left(P<0.05 ; \mathrm{r}_{\mathrm{n} 36}=\right.$ 0.33 ) was found between water level in April and the NAO index in the previous month (Fig. 4).

Also, the water level in Lake Engure water appeared to be associated with the Western type of Atmospheric Circulation Index (ACI-W).

Trends of aquatic chemistry. The ionic composition of Lake Engure during the vegetation season in the study period from 1996 to 2010 was typical for Latvia's lakes: hydrocarbonates, calcium and magnesium ions dominated at sampling stations No 1 and 2 (1. boat station and Dzedrupe). There were frequent inflows of brackish waters at sampling station No. 3 (Mērsrags Canal); according to ion ratios in Piper diagrams (Fig. 5) the water chemical composition was influenced by intrusions of sea water. Extremely high concentrations of $\mathrm{Cl}^{-}(1605 \mathrm{mg} / \mathrm{l}), \mathrm{Na}^{+}(1260 \mathrm{mg} / \mathrm{l}), \mathrm{K}^{+}$ $(49 \mathrm{mg} / \mathrm{l}), \mathrm{SO}_{4}{ }^{2-}(225 \mathrm{mg} / \mathrm{l})$ at sampling station No 3 were observed in 2007. Conductivity of water at station No. 3 ranged from 266 to about $6000 \mu \mathrm{S} / \mathrm{cm}$. Mean conductivity at the other two stations was about $300-350 \mu \mathrm{S} / \mathrm{cm}$.

The dominant anion in Lake Engure was $\mathrm{HCO}_{3}{ }^{-}$with concentrations ranging from 130-200 mg/l. Chloride concentration was lower $(15-60 \mathrm{mg} / \mathrm{l})$, but at the sampling station near Mērsrags Canal reached up to $1600 \mathrm{mg} / \mathrm{l}$. The concentration of sulphate was in the range $10-120 \mathrm{mg} / \mathrm{l}$. Calcium was the dominating cation in most of the samples from $\mathrm{L}$. Engure with concentrations up to $60 \mathrm{mg} / \mathrm{l}$. Sodium concentration in water was sometimes very high near the canal.

$\mathrm{pH}$ values of water correspond to an alkaline reaction (7.6-8.8), and a positive trend was observed. An increasing

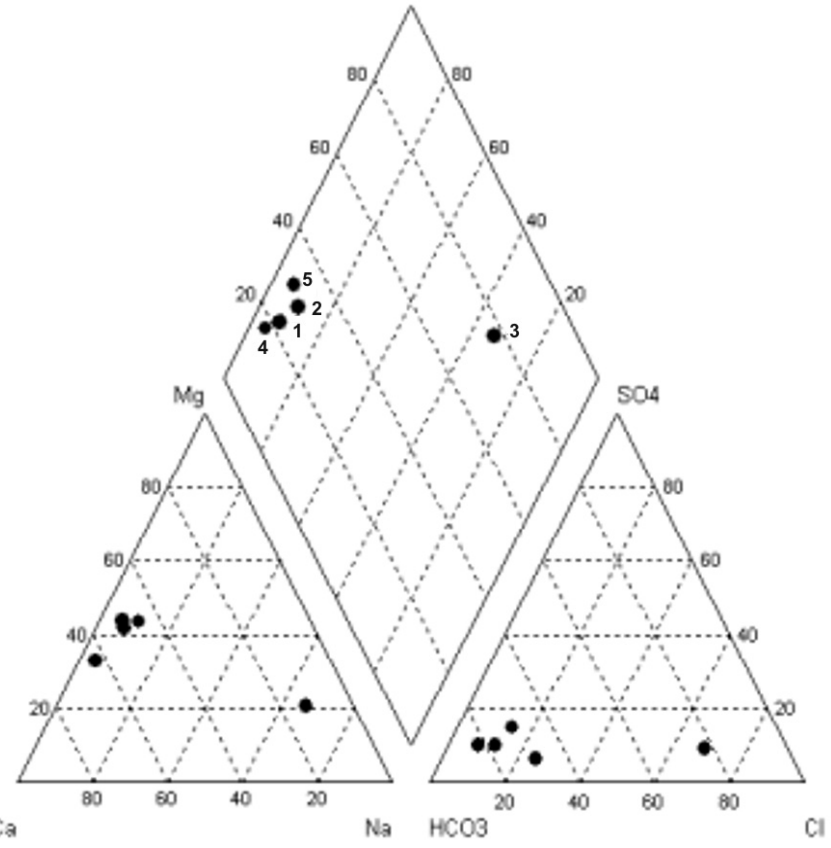

Fig. 5. Piper diagram of lake waters. 1, L. Engure (1 - boat station); 2, L. Engure (R. Dzedrupes); 3, L. Engure (Mērsrags canal); 4, L. Burtnieks; 5, L. Drīdzis.

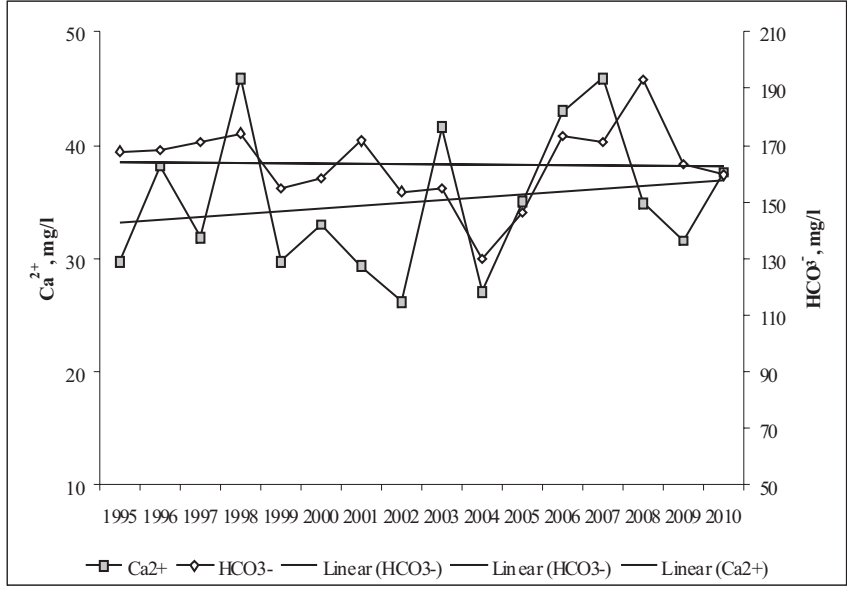

Fig. 6. Trends of changes of $\mathrm{Ca}^{2+}$ and $\mathrm{HCO}_{3}{ }^{-}$ion cojncentrations in waters of Lake Engure.

$\mathrm{pH}$ in water in general is typical in most of Europe due to the effective reduction of pollutant emissions (Marin et al., 2001). In the case of shallow Lake Engure, photosynthetic activity of charophytes and submerged macrophytes could be important, as intensive photosynthesis can raise $\mathrm{pH}$ (Søndergaard, 1988). Concentrations of chlorides; magnesium and sulphates fluctuated, indicating irregular sea-water inflow through the canal (Fig. 7), while concentrations of calcium and bicarbonates have not changed significantly since 1995.

There were no significant differences in water chemistry between sampling points situated closer to river mouth, which may indicate inflow water distribution through the water mass. The lake in general has rather low hydrochemical inertia, which may partly be explained by the water exchange period, which is estimated to vary between 16 and 7 times 


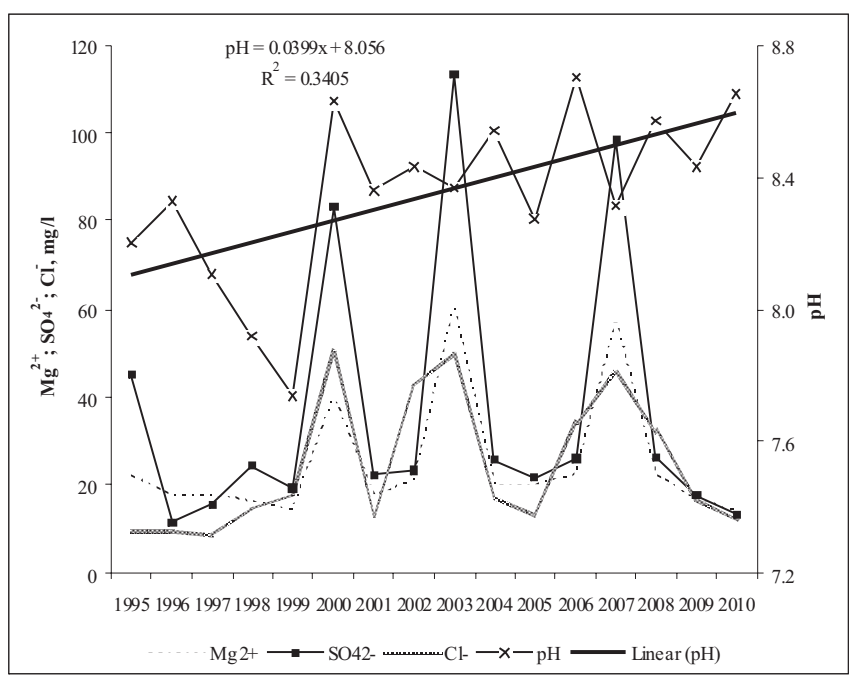

Fig. 7. Trends of changes of $\mathrm{Mg}^{2+}, \mathrm{SO}_{4}{ }^{2-}$ and $\mathrm{Cl}^{-}$ion concentrations and $\mathrm{pH}$ in waters of Lake Engure.

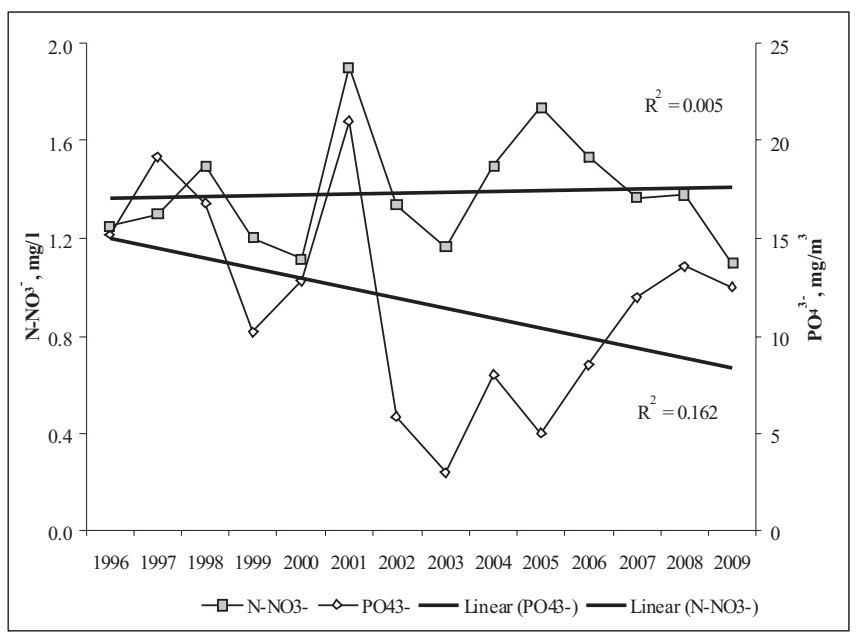

Fig. 8. Trends of changes of $\mathrm{N}^{-\mathrm{NO}_{3}}{ }^{-}$and $\mathrm{PO}_{4}{ }^{3-}$ ion concentrations in waters of Lake Engure.

per year, depending on meteorological conditions. During the low water period, water exchange is approximately once every three months, but in flood period even to four times monthly (Eberhards and Saltupe, 2000).

Since 1995, several physico-chemical changes have occurred. The concentrations of $\mathrm{P}_{-} \mathrm{PO}_{4}{ }^{3-}$ and $\mathrm{N}-\mathrm{NO}_{2}{ }^{-}$have increased, while $\mathrm{N}_{-} \mathrm{NH}_{4}{ }^{+}$and $\mathrm{N}-\mathrm{NO}_{3}{ }^{-}$concentrations have not significantly changed. The $\mathrm{N}: \mathrm{P}$ ratio varied from $38: 1$ to $140: 1$, and a positive trend of this parameter confirms the limiting role of phosphorus (Fig. 9).

Values of $\mathrm{BOD}_{5}$ varied from 2.3 to $5 \mathrm{mg} / \mathrm{l}$ and those of COD from 32.0 to $53 \mathrm{mg} / \mathrm{l}$ without evident trends (Fig. 10) as also for oxygen concentration.

Concentration of organic matter in lake sediments was 24-44\% (Table 2). Concentration of carbonates in Lake Engure sediments differed between sampling stations. At sampling station No. 3 carbonate concentration was $2.75 \%$, similar to the level in most Latvian lakes, but was $23.85 \%$

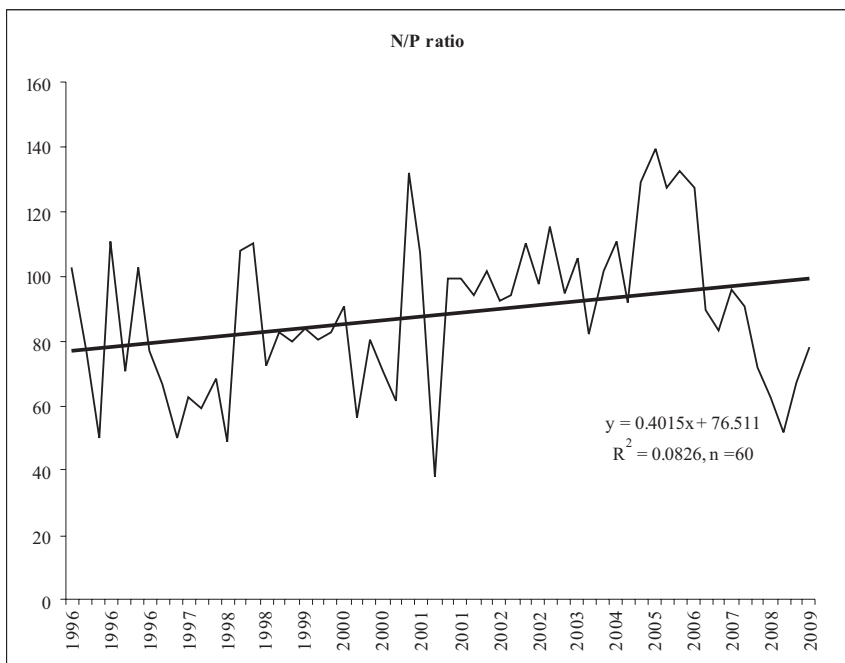

Fig. 9. N/P/ ratio in waters of Lake Engure.

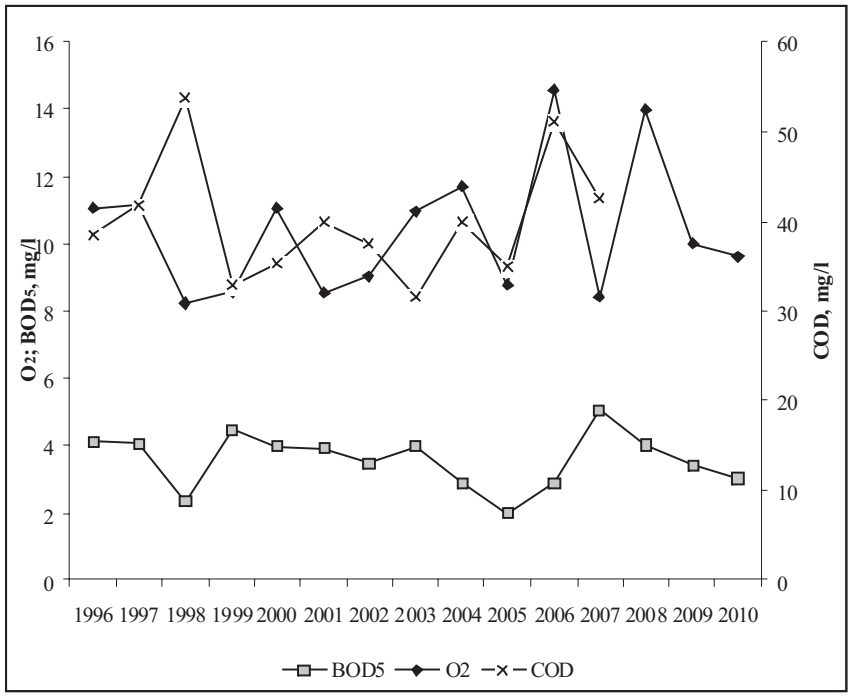

Fig.10. Trends of changes of $\mathrm{COD}, \mathrm{BOD}_{5}$ and $\mathrm{O}_{2}$ in waters of Lake Engure.

at the sampling station No 1. Metal concentrations the upper layer of sediments in Lake Engure were determined by AAS. As it evident from Table 3, the metal concentrations in Lake Engure are lower than in other studied lakes in Latvia. However, concentrations of metals that may be affected by geochemical processes are rather high, especially regarding $\mathrm{Cd}$ and $\mathrm{Zn}(1.53 \mu \mathrm{g} / \mathrm{g}$ and $107 \mu \mathrm{g} / \mathrm{g}$, respectively).

\section{DISCUSSION}

The existing chemical composition of Lake Engure water, and also the structure of aquatic communities are influenced by natural and human induced processes. Global climate change has a major impact, and many indicators of climatic factors are evident. An important manifestation of climate change is the change of large-scale atmospheric circulation processes. The impact of large-scale climate change to Lake Engure involves changes in air temperature, precipitation and water level. Visual inspection (Fig. 3) of climate indica- 
CONCENTRATIONS OF ORGANIC MATTER AND HEAVY METALS IN LAKES OF LATVIA

\begin{tabular}{|c|c|c|c|c|c|c|c|c|c|c|}
\hline Lakes & $\begin{array}{c}\text { OM, } \\
\%\end{array}$ & $\begin{array}{c}\text { Carbonates, } \\
\% \\
\end{array}$ & $\begin{array}{c}\mathrm{P}_{\text {tot }} \\
\mathrm{mg} / \mathrm{kg}\end{array}$ & $\begin{array}{c}\mathrm{Cr}, \\
\mathrm{mg} / \mathrm{kg}\end{array}$ & $\begin{array}{c}\mathrm{Co}, \\
\mathrm{mg} / \mathrm{kg}\end{array}$ & $\begin{array}{c}\mathrm{Ni}, \\
\mathrm{mg} / \mathrm{kg}\end{array}$ & $\begin{array}{c}\mathrm{Cu}, \\
\mathrm{mg} / \mathrm{kg}\end{array}$ & $\begin{array}{c}\mathrm{Zn}, \\
\mathrm{mg} / \mathrm{kg}\end{array}$ & $\begin{array}{c}\mathrm{Cd}, \\
\mathrm{mg} / \mathrm{kg}\end{array}$ & $\begin{array}{c}\mathrm{Pb}, \\
\mathrm{mg} / \mathrm{kg}\end{array}$ \\
\hline Engure No. 1 & 24.3 & 23.85 & 58.5 & 4.6 & 1.5 & 6.0 & 8.8 & 40.4 & 0.31 & 19.8 \\
\hline Engure No. 3 & 44.2 & 2.75 & 342.1 & 8.0 & 2.9 & 7.5 & 9.2 & 53.8 & 0.30 & 10.3 \\
\hline Alauksts & 38.5 & 2.22 & 807.5 & 32.8 & 9.6 & 23.4 & 22.0 & 121.7 & 1.02 & 61.6 \\
\hline Alūksnes & 3.0 & 0.26 & 172.3 & 2.9 & 1.7 & 2.1 & 2.4 & 10.2 & 0.12 & 2.2 \\
\hline$\overline{\text { Ārdavs }}$ & 39.6 & 1.68 & 554.1 & 26.3 & 7.2 & 20.5 & 19.6 & 70.1 & 0.12 & 23.6 \\
\hline Bešons & 18.5 & 2.19 & 753.4 & 38.2 & 11.8 & 26.5 & 22.6 & 102.5 & 0.35 & 30.7 \\
\hline Drīdzis & 11.1 & 2.02 & 608.1 & 33.5 & 12.7 & 25.8 & 24.6 & 74.3 & $<0.03$ & 19.4 \\
\hline Ežezers & 29.8 & 3.05 & 601.4 & 33.9 & 9.3 & 24.0 & 24.5 & 115.6 & 0.58 & 35.2 \\
\hline Galšūns & 20.8 & 3.92 & 1601.5 & 23.5 & 9.0 & 16.0 & 22.1 & 88.1 & 0.22 & 28.8 \\
\hline Lejas & 12.5 & 1.78 & 767.0 & 27.4 & 9.7 & 19.9 & 19.0 & 75.5 & 0.06 & 15.4 \\
\hline Nirza & 19.8 & 2.17 & 763.6 & 25.2 & 9.8 & 18.5 & 22.8 & 84.6 & 0.40 & 24.9 \\
\hline Rāzna 5 & 5.0 & 1.95 & 342.9 & 6.1 & 2.0 & 2.9 & 3.7 & 21.7 & 0.12 & 6.8 \\
\hline Sīvers & 35.0 & 1.57 & 500.0 & 20.0 & 6.6 & 16.1 & 19.0 & 64.2 & 0.57 & 24.8 \\
\hline Svente & 17.9 & 2.40 & 594.6 & 42.3 & 9.3 & 28.9 & 18.4 & 77.6 & 0.33 & 28.9 \\
\hline Zosna & 46.2 & 3.99 & 780.5 & 15.6 & 7.1 & 11.5 & 10.7 & 128.4 & 0.33 & 13.1 \\
\hline
\end{tabular}

tors for the last $\sim 80$ years reveal clear trends, and the increase of annual mean temperatures clearly indicates warming.

Trend analyses of long-term temperature series showed a statistically significant increase of annual mean temperature by $1.04{ }^{\circ} \mathrm{C}$ for the period $1928-2007$ (test statistic $2.31 ; P=$ $0.01)$. Significant increasing temperature trends were also found for spring (March-May) period (test statistic 3.31; $P=0.005)$ and winter (Dec-Febr) season (test statistic 2.02; $P<0.05)$.

The average annual amount of precipitation at Mērsrags for the studied period (1928-2007) was $593 \mathrm{~mm}$. The results of long-term precipitation trend analysis show an increase of annual mean precipitation (test statistic 2.79; $P<0.01$ ), with the most pronounced significant increase in the winter period (normalized test statistic: $5.15 ; P=0.0000$ ).

Mean daily temperature, mean daily minimum temperature and the mean daily maximum temperature all showed positive trends over the study period (Table 1), which however was not significant for mean daily minimum air temperature. Due to increasing temperature, the number of growing degree days and growing season length have increased slightly. The significant increase in the mean air temperature is associated with an increase in the mean diurnal temperature range, due to a greater increase in the daily maximum air temperatures compared to daily minimum air temperatures.

Besides the mean values of climatic factors, also the extreme values of air temperature have been increasing. There has been an increase in the number of days with extremely high temperatures and a decrease in the number of days with extremely low air temperatures (Table 2). The number of frost days ( $\mathrm{TN}<0{ }^{\circ} \mathrm{C}$ ), ice days ( $\mathrm{TX}<0{ }^{\circ} \mathrm{C}$ ), cold-spell days and the number of maximum consecutive frost days $\left(\mathrm{TN}<0{ }^{\circ} \mathrm{C}\right)$ demonstrate a decreasing trend. The climatic indicators of positive temperature extremes, for example the number of summer days $\left(\mathrm{TX}>25^{\circ} \mathrm{C}\right.$ ) and the number of tropical nights $\left(\mathrm{TN}>20^{\circ} \mathrm{C}\right)$, demonstrate increasing trends. There has also been a statistically significant increase in the number of days with heavy precipitation (daily precipitation total $\geq 10 \mathrm{~mm}$ ) and very heavy precipitation (daily precipitation total $\geq 20 \mathrm{~mm}$ ). The clear increase of precipitation may be associated with the influence of the Gulf of Riga.

An important indicator of large-scale climatic processes is NAO oscillation. A positive NAO index in winters is related to a western atmospheric transfer that results in increased precipitation and higher temperature in the Lake Engure basin. As in the Northern Hemisphere, there are three types of atmospheric circulation (zonal -Western and Eastern, and meridional) (Girs, 1971). In Lake Engure, there was a good relationship between lake water level and the Western type of Atmospheric Circulation Index (ACI).

Lake Engure can be considered as a unique study area, since the first chemical analyses of lake waters were conducted more than 100 years ago. The first documentation related to morphological characteristics and hydrochemical composition of the lake water is dated to the beginning of the previous century (Ludwig, 1908). In two probes conducted at that time, the concentration of dissolved oxygen was 6.8 and $7.2 \mathrm{mg} / \mathrm{l}$ (Winkler's method), which is lower than that observed today. Concentrations of phosphate and nitrogen were low indicating that eutrophication was not an important factor (Ludwig, 1908). The amount of organic matter in lake sediments from the beginning of century till 2010 has increased from $29 \%$ to $44 \%$. Ludwig (1908) also noted inflow of brackish water through the canal. He found that concentrations of chloride, potassium and sodium ions at a 
Table 4

IONIC RATIOS OF LAKE ENGURE, LAKE DRİDZIS AND LAKE RĀZNA

\begin{tabular}{l|c|c|c|c|c}
\hline \multicolumn{1}{c|}{ Sampling station } & $\begin{array}{c}\text { Station } \\
\text { No. 1 }\end{array}$ & $\begin{array}{c}\text { Station } \\
\text { No. 2 }\end{array}$ & $\begin{array}{c}\text { Station } \\
\text { No. 3 }\end{array}$ & L. Drīdzis & L. Rāzna \\
\hline Ionic ratios & 0.30 & 0.29 & 0.42 & 0.22 & 0.21 \\
$\mathrm{Na}^{+} /\left(\mathrm{Na}^{++} \mathrm{Cl}^{-}\right)$ & 0.54 & 0.69 & 0.40 & 0.81 & 0.90 \\
$\mathrm{Ca}^{2+} /\left(\mathrm{Ca}^{2++} \mathrm{SO}_{4}{ }^{2-}\right)$ & 0.09 & 0.08 & 0.57 & 0.08 & 0.10 \\
$\mathrm{Cl}-/ \Sigma$ anions & 0.80 & 0.80 & 0.30 & 0.90 & 0.90 \\
$\mathrm{HCO}-/ \Sigma$ anions & 0.37 & 0.33 & 0.50 & 0.34 & 0.32 \\
$\mathrm{Mg}^{2+} /\left(\mathrm{Mg}^{2++} \mathrm{Ca}^{2+}\right)$ & & & & &
\end{tabular}

sampling station near the canal were twice as high as in the middle part of the lake.

At present, Lake Engure, according to its chemical composition, is a relatively little polluted lakes and development of eutrophication is hampered due to intensive growth of macrophytes along the coastline and due to intensive development of submerged macrophyte vegetation. In the shallow Lake Engure, the contribution of photosynthesis by charophytes and submerged macrophytes can raise the $\mathrm{pH}$ (Søndergaard, 1988). High concentrations of dissolved oxygen also support intensive photosynthesis. The increasing $\mathrm{pH}$ values in general are typical of most European lakes, due to the effective reduction of pollutant emissions (Marin et al., 2001).

The composition of inorganic ions during the study period has changed relatively little, and an important factor influencing lake water quality is frequent inflow of brackish waters through the Mērsrags canal.

Increased values of some ionic ratios, e.g., $\mathrm{Na}^{+} /\left(\mathrm{Na}^{+}+\mathrm{Cl}^{-}\right)$, $\mathrm{Cl}^{-} /$Sanions or $\mathrm{Mg}^{2+} /\left(\mathrm{Mg}^{2+}+\mathrm{Ca}^{2+}\right)$ at sampling station No 3 indicate intrusion of sea-water. The ratio $\mathrm{HCO}_{3}{ }^{-} / \Sigma$ anions was 0.30 at sampling station No. 3 , indicating inflow of brackish water. At other stations in Lake Engure and in lakes Dridzis and Rāzna, which are situated in Eastern part of Latvia, this ratio is $0.80-0.90$ indicating silicate and carbonate weathering processes (Hounslow, 1995) (Table 4). Inflow of sea waters through Mērsrags canal also affects species composition, e.g., oligohaline and mesohaline species of benthic invertebrates are found at sampling station No. 3 (Skuja et al., 2011).

Concentrations of nutrients fluctuate significantly. P-phosphate concentrations have a decreasing trend, probably due to reduction of agricultural activities in the lake basin and intensive accumulation of phosphorous in the abundant vegetation. From this perspective, the increase of the N/P ratio is interesting (Fig. 8) as it is an important factor affecting lake ecosystem function. Intensive development of vegetation and an increase of N/P ratio indicate that the availability of phosphorus limits eutrophication. This indicates the main direction of the management of the lake.

The analyses of heavy metals in lake sediments is a useful method for study of environmental pollution. Usually, sedi- ments act as traps for most heavy metals by forming complexes with organic matter, carbonates and iron-manganese oxides. Primary production of Charophyte beds can influence sediment chemistry, e.g., the high carbonate concentration at sampling station No. 1 might be due to calcite precipitation (Kufel and Kufel, 2002)

In conclusion, ecosystem function of Lake Engure is influenced by global climate change processes, as climatic factors demonstrate increasing trends, and since extreme events are occurring more frequently. Lake Engure is a lagoon lake, but chemical composition of water and sediment are typical for most lakes in Latvia. Lake sediment chemistry is influenced by charophyte vegetation. In general, hydrochemical composition has been quite stable during the period of observation. Indicators of anthropogenic eutrophication (nutrient concentrations, BOD, etc) in lake have not been increasing. The trophic status and characteristics of biological processes depend on amounts of nutrients bound in sediments and on macrophytes and lake morphometry. The observed concentrations of pollutants (using $\mathrm{BOD}_{5}$, COD) from catchment area are relatively low, but taking into account the sensitivity of the system, it is very important to ensure that an increase of nutrients does not occur in the future.

\section{ACKNOWLEDGEMENTS}

This work was supported in part by the Latvian Research Council Cooperative project "Development of conceptual integrated model of socioeconomic biodiversity pressures, drivers and impacts for the long-term socioecological research platform of Latvia” and ESF grant No. 2009/0214/ 1DP/1.1.1.2.0/09/APIA/VIAA/089.

\section{REFERENCES}

Anonīms (1995). Engures ezers. Grām.: Latvijas Enciklopēdija. 2. sēj. Rīga, 50-51. 1pp.

Anonymous (1992b). Standard Methods for the Examination of Water and Wastewater. 18th edn. Washington, DC: APHA, AWWA, WPCF. $1193 \mathrm{pp}$.

Anonymous (2011). Monitoring air and climate. Available at http://www.cpc.noaa.gov/products/precip/CWlink/pna/nao_index.html.

Briede, A, Kḷaviņš, M. (1999). Phosphorous speciation in sediments of Lake Mazais Baltezers, Latvia. Proc. Latv. Acad. Sci, Section B, 53(1), 48-54.

Csuros, M., Csuros, C. (2002). Environmental Sampling and Analysis for Metals. CRC Press. 408 pp.

Eberhards, G., Saltupe, B. (2000). Geological history, relief, and deposits of the Lake Engures (Engure) area along the Baltic Sea. Proc. Latv. Acad. Sci., Section B, 54, 141-147.

Eberhards, G., Grine, I., Lapinskis, J., Purgalis, I., Saltupe, B., Torklere, A. (2009). Changes in Latvia's seacoast (1935-2007), Baltica, 22, 11-22.

Klein Tank, A.M.G. (2004). Changing Temperature and Precipitation Extremes in Europe's Climate of the $20^{\text {th }}$ Century. Available at http://eca.knmi.nl/documents/Thesis_KleinTank_2004.pdf.

Libiseller, C., Grimvall, A. (2002). Performance of partial Mann-Kendall test for trend detection in the presence of covariates. Environmetrics, 13, 71-84. 
Ludwig, F. (1908). Die Küstenseen des Rigaer Meeresbusens. Arbeiten des Naturforschers-Vereins zu Riga, 11, 1-198.

Heiri, O., Lotter, A.F., Lemcke, G. (2001). Loss on ignition as a method for estimating organic and carbonate content in sediments: Reproducibility and comparability of results. J. Paleolimnol., 25, 101-110

Hounslow, A.W. (1995). Water Quality Data. Analysis and Interpretation. CRCPress Inc.

Jaagus, J. (2006). Climatic changes in Estonia during the second half of the $20^{\text {th }}$ century in relationships with changes in large-scale atmospheric circulation. Theor. Appl. Climatol., 83, 77-88.

Kufel L., Kufel I. (2002). Chara beds acting as nutrient sinks in shallowlakes - a review. Aquat. Bot., 72, 249-260.

Marin, E., Pérez-Amaral, T., Rúa A., Hernández, E. (2001). The evolution of the $\mathrm{pH}$ in Europe (1986-1997) using panel data. Chemosphere, 45, 329-337.

Received 15 November 2011
Skuja, A., Parele, E., Ozolinšs, D. (2011). Engures ezera makrozoobentosa sabiedrību izplatības telpiskais raksturojums, 1995-2008. Ģeogrāfija. Gieologiija. Vides zinātne. Referātu tēzes [Spatial characteristics of the distribution of macrozoobentos communities of Lake Engure, 1995-2008. Geography. Geology. Environmental Sciences. Abstracts] (284.-285. lpp.). Rīga: LU (in Latvian).

Søndergaard, M. (1988). Seasonal variations in the loosely sorbed phosphorus fraction of the sediment of a shallow and hypereutrophic lake. Environ. Geol., 11, 115-121.

Søndergaard, M., Jensen \& E. Jeppesen, P.J. (2001). Retention and internal loading of phosphorus in shallow, eutrophic lakes. Sci. World J., 1, $427-442$.

Vīksne, J. (1997). The Bird Lake Engure. Rīga: Jāṇa sēta. 111 pp.

Гирс А.А. (1971). Многолетние колебания атмосферной цииркуляции и долгосрочные гидрометеорологические прогнозы [Long-term Fluctuations of Atmospheric Circulation Patterns and Its Forecasts]. Ленинград: Гидрометеоиздат. 279 с.

\section{ENGURES EZERA HIDROMETEOROLOG̦ISKO PARAMETRU UN ŪDEN̦U K̦İMISKĀ SASTĀVA MAINĪBAS TENDENCES: ANTROPOGĒNO FAKTORU UN DABISKĀS MAINĪBAS IETEKMES}

Engures ezers kā Rīgas līča piekrastes seklūdens ezers, kas izveidojies, atkāpjoties Litorīnas jūrai, ir nacionāli un starptautiski nozīmīgs, ņemot vērā tā ekosistēmu augsto bioloğisko daudzveidību. Engures ezera ūdeņus raksturo augsta cietība, kas ietekmē iegremdētās un piekrastes joslas veǵetāciju. Pētījumā izvērtēts galveno hidrometeoroloǵisko parametru un klimata indikatoru (it īpaši ekstremālo klimatisko parādību) mainības raksturs un pierādītas globāli noritošās pasiltināšanās ietekmes. Esošo ezera ūdens līmeni nosaka hidrotehnisko būvju izveide, bet gada siltajā periodā ir raksturīgs ūdens līmeṇa pieaugums, turklāt ilgtermiṇā ezera ūdens līmeṇa izmaiṇas ietekmē atmosfēras gaisa masu pārnese no Ziemeḷatlantijas. Pierādīta korelācija starp Ziemeḷatlantijas oscilācijas indeksu martā un ezera ūdens līmeni aprīlī. Ūdens kīmiskā sastāva izmaiņas raksturo fosfora koncentrāciju samazināšanās un relatīvi stabilas slāpekḷa savienojumu koncentrācijas. Neorganisko jonu kompozīciju raksturo kalcija, magnija un hidrogēnkarbonātjonu dominance. 